\title{
Bartonella chomelii sp. nov., isolated from French domestic cattle (Bos taurus)
}

\author{
Renaud Maillard, ${ }^{1,3}$ Philippe Riegel, ${ }^{2}$ Francine Barrat, ${ }^{1}$ Corinne Bouillin, ${ }^{1}$ \\ Danielle Thibault, ${ }^{1}$ Christelle Gandoin, ${ }^{1}$ Lénaig Halos, ${ }^{1}$ \\ Christine Demanche, ${ }^{1}$ Annie Alliot, ${ }^{1}$ Jacques Guillot, ${ }^{1}$ Yves Piémont, ${ }^{2}$ \\ Henri-Jean Boulouis ${ }^{1}$ and Muriel Vayssier-Taussat ${ }^{1}$ \\ ${ }^{1}$ UMR 956 INRA/AFSSA/ENVA/UPVM, Microbiologie, Ecole Nationale Vétérinaire, 7 Avenue \\ du Général de Gaulle, 94704 Maisons-Alfort, France \\ ${ }^{2}$ Institut de Bactériologie de la Faculté de Médecine, Université Louis Pasteur, Hôpitaux \\ Universitaires de Strasbourg, 3 rue Koeberlé, 67000 Strasbourg, France \\ 3Unité de Pathologie du Bétail, Ecole Nationale Vétérinaire, 7 Avenue du Général de Gaulle, \\ 94704 Maisons-Alfort, France
}

Correspondence Henri-Jean Boulouis hjboulouis@vet-alfort.fr

\section{INTRODUCTION}

In recent years, the genus Bartonella has undergone a rapid expansion, from the initially described Bartonella bacilliformis to 18 species that are currently recognized (Bermond et al., 2002). Bartonella species are small Gram-negative bacteria, often piliated or flagellated. They are intracellular parasites of red blood cells and endothelial cells. In reservoir hosts, Bartonella infections usually result in asymptomatic bacteraemia. This bacteraemic phase is required for the long-term perpetuation of the bacterium, allowing its transmission by blood-sucking arthropods (Breitschwerdt \& Kordick, 2000; Chomel et al., 1996; Alexander, 1995). Some species of Bartonella are able to infect not only reservoir hosts, but also accidental hosts for which the bacterium is not adapted or poorly adapted. In this case, infections are associated with human or animal diseases including cat scratch disease (CSD), bacillary angiomatosis,

Published online ahead of print on 1 August 2003 as DOI 10.1099/ ijs.0.02770-0.

The GenBank accession numbers for the 16S rRNA and $3^{\prime}$ end gltA sequences of Bartonella chomelii are AY254309 and AY254308, respectively.

A tree showing the phylogenetic relationships of Bartonella species inferred from $16 S$ rRNA sequences, and a table of DNA-DNA hybridization data, and 16S rRNA and gt/A gene similarity are available in IJSEM Online. peliosis hepatitis and endocarditis, in either immunocompetent or immunocompromised patients (Breitschwerdt \& Kordick, 2000).

To date, molecular characterization of Bartonella species has included PCR amplification of protein-coding genes (Houpikian \& Raoult, 2001a), as well as the 16S rRNA gene (Birtles, 1995) and the 16S-23S rRNA intergenic spacer region (ITS) (Jensen et al., 2000). The degree of identity of these genes among Bartonella species has then been assessed both indirectly, by using RFLP analysis (Birtles, 1995; Joblet et al., 1995; Norman et al., 1995; Houpikian \& Raoult, 2001b), and directly by base sequence comparisons. While 16S rDNA has been shown to be a powerful tool for appreciating genetic variability among Bartonella species, the protein-encoding genes appear to be good indicators of interspecies divergence and RFLP-PCR on the gltA gene is often used to identify Bartonella species in biological samples (La Scola et al., 2003).

Recently, three Bartonella species have been isolated from ruminants. Two of these (Bartonella schoenbuchensis and Bartonella capreoli) were recovered from wild roe deer (Capreolus capreolus) (Dehio et al., 2001; Bermond et al., 2002), and a third one (Bartonella bovis) from domestic cattle (Bermond et al., 2002). All of these three species appear to be adapted to ruminants. In view of the potential zoonotic pathogenicity of Bartonella and the high exposure 
of humans to ruminants through consumption of bovinederived products or hunting practices, the risk of zoonotic transmission of ruminant-derived Bartonella to humans should not be underestimated.

\section{METHODS}

Animals, blood samples and culture conditions. During routine surveys of Bartonella bacteraemia in two cattle herds in two regions in France (Loire-Atlantique and Nord departments), blood samples $(4 \mathrm{ml})$ were collected from cows over a 3 year period (2000-2002). Blood samples were collected into EDTA plastic tubes (Greiner Vacuette). All tubes were frozen and stored at $-80^{\circ} \mathrm{C}$ until tested. After thawing, the blood samples were centrifuged at $1800 \mathrm{~g}$ for $75 \mathrm{~min}$ and then plated onto agar plates containing $5 \%$ fresh defibrinated rabbit blood. Plates were incubated at $35^{\circ} \mathrm{C}$ in a moist $5 \% \mathrm{CO}_{2}$ atmosphere for 6 weeks.

Bacterial strains. One hundred and fifty bacterial strains isolated from 75 cows were identified using PCR amplification followed by analysis of the RFLP-profile of the gltA gene (citrate synthase) using TaqI, MseI, HhaI and DdeI restriction enzymes as described previously (Birtles \& Raoult, 1996; Norman et al., 1995), according to the manufacturer's instructions (New England Biolabs)

Electron microscopy. Bacteria were grown on Columbia base agar (bioMérieux) plates containing $5 \%$ fresh defibrinated rabbit blood for 5 days. Bacteria were then suspended in PBS, spread on a water surface and absorbed to Formvar-coated nickel grids, stained with $1 \%(\mathrm{w} / \mathrm{v})$ uranyl acetate and air-dried (Fusseneger et al., 1996). Samples were examined with a JEOL 100CX2 electron microscope.

Biochemical analysis. Bartonella species are biochemically inert in almost all conventional tests. Biochemical assays performed with diagnostic tablets (Rosco; Eurobio) were as follows: VogesProskauer reaction, tributyrin hydrolysis, pyrazinamidase, proline aminopeptidase and trypsin-like activity. Commercially available reagents (Rapid ID 32 A; bioMérieux) were used to test the activity of bacterial enzymes according to the manufacturer's instructions.

Reference strains used for DNA-DNA hybridization. Bartonella grahamii $\left(\mathrm{V} 2^{\mathrm{T}}\right.$, ATCC $49927^{\mathrm{T}}$ ), Bartonella clarridgeiae (Houston- $2^{\mathrm{T}}$, ATCC $\left.51734^{\mathrm{T}}\right)$, Bartonella elizabethae $\left(\mathrm{F} 9251^{\mathrm{T}}\right.$, ATCC $49927^{\mathrm{T}}$ ), Bartonella henselae (Houston-1 G5436 ${ }^{\mathrm{T}}$, ATCC $49882^{\mathrm{T}}$ ), Bartonella koehlerae $\left(\mathrm{C} 29^{\mathrm{T}}\right.$, ATCC $\left.700693^{\mathrm{T}}\right)$, Bartonella quintana $\left(\right.$ Fuller ${ }^{\mathrm{T}}$, ATCC VR-358 ${ }^{\mathrm{T}}$ ), Bartonella doshiae (R18 ${ }^{\mathrm{T}}$, ATCC $700133^{\mathrm{T}}$ ), Bartonella vinsonii subsp. vinsonii $\left(\mathrm{Baker}^{\mathrm{T}}\right.$, ATCC VR-152 ${ }^{\mathrm{T}}$ ), Bartonella vinsonii subsp. berkhoffii (ATCC $51672^{\mathrm{T}}$ ) and Bartonella bacilliformis (ATCC $35685^{\mathrm{T}}$ ) were purchased from the American Type Culture Collection (ATCC, Manassas, VA, USA). Bartonella taylorii $\left(\mathrm{M6}^{\mathrm{T}}, \mathrm{CIP} 107028^{\mathrm{T}}\right)$ was purchased from the Collection of the Pasteur Institute (CIP, Paris, France). Bartonella alsatica (IBS $382^{\mathrm{T}}$, CIP $105477^{\mathrm{T}}$ ), Bartonella birtlesii (IBS $325^{\mathrm{T}}$, CIP $\left.106294^{\mathrm{T}}\right)$, Bartonella bovis $\left(91-4^{\mathrm{T}}\right.$, CIP $106692^{\mathrm{T}}$ ), Bartonella capreoli (IBS $193^{\mathrm{T}}$, CIP $106691^{\mathrm{T}}$ ), Bartonella schoenbuchensis $\left(\mathrm{R} 1^{\mathrm{T}}\right.$, NCTC $13165^{\mathrm{T}}$ ) and Bartonella tribocorum (IBS 506 ${ }^{\mathrm{T}}$, CIP $105476^{\mathrm{T}}$ ) were kindly given by one of the authors.

DNA-DNA hybridization. DNA extraction and purification were performed as described by Riegel et al. (1994). DNA hybridization between labelled DNA and unlabelled fragmented DNAs was performed at $58^{\circ} \mathrm{C}$ for $16 \mathrm{~h}$ in $0.42 \mathrm{M} \mathrm{NaCl}$ using the nuclease/ trichloroacetic method (Grimont et al., 1980; Riegel et al., 1994). When the percentage hybridization was above $30 \%$, experiments were performed in triplicate. Therefore, the given value represents the mean of triplicate values \pm standard deviation.

Amplification and sequencing of the 16S rRNA and citrate synthase genes. A fragment of approximately $1500 \mathrm{bp}$ of the
16S rRNA gene was amplified from the extracted DNA by using eubacterial universal primers specific for $16 \mathrm{~S}$ rRNA gene: P8 $\left(5^{\prime}-\right.$ AGAGTTTGATCCTGGCTCAG-3') and Pc1544 (5'-AAGGAGGTGATCCAGCCGCA-3') (Heller et al., 1997). PCR amplification of a $350 \mathrm{bp}$ fragment of the citrate synthase gene was performed as described by Norman et al. (1995) with primers BhCS.781p (5'-GGGGACCAGCTCATGGTGG-3') and BhCS.1137 (5'-AATGCAAAAAGAACAGTAAACA-3') (Norman et al., 1995). The presence and size of the amplicons were verified by electrophoresis on a $1.5 \%$ agarose gel, followed by ethidium bromide staining and visualization on a UV transilluminator.

Amplified fragments were sent to Genome express (Meylan, France) for sequencing. Sequencing of the almost complete $16 \mathrm{~S}$ rRNA gene was performed bidirectionally, using three primer pairs: $\mathrm{P} 8$ and PC535 (5'-GTATTACCGCGGCTGCTGGCA-3'), P350F (5'-CTCCTACGGGAGGCAGCAGT- $3^{\prime}$ ) and P785R (5'-GGGTATCTAATCC$\left.3^{\prime}\right)$, and P535F (5' ${ }^{\prime}$ TGCCAGCAGCCGCGGTAATAG-3') and Pc1544.

Sequence alignment and tree construction. The $16 \mathrm{~S}$ rRNA and gltA sequences obtained in this study were aligned with sequences from other Bartonella species first with CLUSTAL X software (version 1.63b, December 1997; Thompson et al., 1997) and then by visual optimization. The alignments are available upon request. Nucleic acid sequences of gltA were then translated into amino acid sequences. The aligned sequences were converted to a distance matrix (percentage differences without weighting). A distance tree was generated using the neighbour-joining method (Saitou \& Nei, 1987). Both the branch-and-bound and heuristic search options in the PAUP program version 4.0 (Swofford, 1993) were used for comparison of sequence alignments and generation of parsimonious trees. The statistical support of the internal branches from the resulting trees was statistically tested by bootstrap analysis (Felsenstein, 1985) from 500 bootstrap replications. The list of the Bartonella species used for the phylogenetic analysis is indicated in Fig. 2 and the $16 \mathrm{~S} \mathrm{rDNA}$ tree is available as supplementary data in IJSEM Online. The 16S rRNA and the gltA sequences of Rickettsia rickettsii were used as outgroups.

Nucleotide sequence accession numbers. The strain designation and GenBank accession numbers for the sequences derived from 16S rRNA and gltA gene analysis are shown in Fig. 2 and the $16 \mathrm{~S}$ rDNA tree available as supplementary data in IJSEM Online.

\section{RESULTS AND DISCUSSION}

\section{Isolation of a new RFLP-type bovine Bartonella}

The gltA gene was amplified from 150 isolates derived from 75 bovine RFLP profiles and was analysed and compared with other known Bartonella species, in particular with those derived from ruminants, i.e. Bartonella capreoli, Bartonella bovis and Bartonella schoenbuchensis. Two distinct profiles were obtained, one corresponding to Bartonella bovis (Bermond et al., 2002) and characterized by the presence of restriction sites for TaqI and Msel, but not HhaI and DdeI, and a second RFLP profile different from that of other known Bartonella species and characterized by the presence of restriction sites for MseI, but not TaqI, HhaI and Dde (Table 1).

Among the 150 isolates, 148 presented an RFLP profile identical to that of Bartonella bovis, while two presented a new RFLP profile. 
Table 1. PCR/RFLP profiles of the citrate synthase gene of isolates from French cattle with Taql, Msel, Ddel and Hhal compared to known Bartonella species

- , Undigested.

\begin{tabular}{|c|c|c|c|c|}
\hline Isolate/Bartonella species & TaqI & MseI & DdeI & HhaI \\
\hline $\begin{array}{l}\text { Isolates corresponding to Bartonella bovis } \\
\text { Isolates corresponding to new profile }\end{array}$ & $250+100$ & $220+150$ & - & - \\
\hline $\mathrm{A} 828^{\mathrm{T}}$ & - & $180+<100$ & - & - \\
\hline A12.90 & - & $180+<100$ & - & - \\
\hline Bartonella alsatica & $250+100$ & $150+<100$ & - & - \\
\hline Bartonella schoenbuchensis & - & 180 & 250 & - \\
\hline Bartonella capreoli & - & $180+120$ & $250+100$ & - \\
\hline Bartonella clarridgeiae & - & $250+150$ & $250+100$ & $250+100$ \\
\hline Bartonella henselae & $220+150$ & $250+150$ & - & $200+150$ \\
\hline Bartonella tribocorum & - & 150 & - & $250+120$ \\
\hline Bartonella vinsonii subsp. berkhoffii & $220+150$ & $220+<100$ & - & - \\
\hline
\end{tabular}

The high prevalence of Bartonella bovis bacteraemia in domestic cattle in the absence of any apparent pathological effect strongly suggests that domestic cows are a natural reservoir of Bartonella bovis (Chang et al., 2001). In contrast, the low prevalence of this new Bartonella species in cattle suggests that this animal species might not be its natural reservoir, but rather an accidental host. If this hypothesis proves to be true, the potential for pathogenicity of $A 828^{\mathrm{T}}$ in cows would warrant further investigation. Therefore, these two strains (A828 ${ }^{\mathrm{T}}$ and A12.90) sharing the same new RFLP profile and originating from two different herds were selected for further species characterization.

\section{Phenotypic characterization}

The $\mathrm{A} 828^{\mathrm{T}}$ and A12.90 isolates displayed similar morphological characteristics. They both grew slowly (10 days for primary isolation), required $\mathrm{CO}_{2}$ and produced smooth colonies, 2-3 $\mathrm{mm}$ in diameter with straight and slender Gram-negative bacilli. Both of them were able to grow on rabbit blood and sheep blood agar plates, but with a higher efficiency on rabbit blood agar plates. Like other Bartonella species, they were oxidase- and catalase-negative, had a negative Voges-Proskauer reaction and a positive reaction for tributyrin. Results of amino acid arylamidase activity, using the rapid ID 32A system, are given in the species description below.

Electron microscopic examination of a subculture of isolate $A 828^{\mathrm{T}}$ revealed bacilli with multiple unipolar flagella (Fig. 1).

\section{$16 S$ rRNA and citrate synthase gene sequence analysis}

The $\mathrm{A} 828^{\mathrm{T}}$ and A12.90 isolates had an identical 16S rRNA gene sequence. This sequence was most similar to $16 \mathrm{~S}$ rRNA gene sequences from Bartonella species, but was different from that of all other Bartonella species or isolates available in the EMBL/GenBank database (a table is available as supplementary data in IJSEM Online). The $16 \mathrm{~S}$ rRNA gene of $A 828^{\mathrm{T}}$ was most closely related to three ruminantderived species, i.e. Bartonella schoenbuchensis (99.6\%), Bartonella capreoli (99.0\%) and Bartonella bovis (98.9\%). The $16 \mathrm{~S}$ rRNA sequence of $\mathrm{A} 828^{\mathrm{T}}$ displayed approximately $97 \%$ identity with the $16 \mathrm{~S}$ rRNA gene from other Bartonella species.

For gltA sequences, $\mathrm{A} 828^{\mathrm{T}}$ and A12.90 had identical $3^{\prime}$ end sequences, which differed from those of the 18 other type strains of Bartonella and the other unidentified Bartonella isolates contained in the EMBL/GenBank database.

As for the 16S rRNA gene, the $3^{\prime}$-end sequence of gltA of $\mathrm{A} 828^{\mathrm{T}}$ was closest to species isolated from ruminants, i.e. Bartonella schoenbuchensis $(96 \cdot 2 \%)$, Bartonella capreoli $(94 \cdot 8 \%)$ and Bartonella bovis $(92 \cdot 9 \%)$. The most distant gltA gene sequence was that of Bartonella bacilliformis $(82 \cdot 0 \%)$. These data, together with the culture characteristics (colonial morphology, duration of bacterial growth,

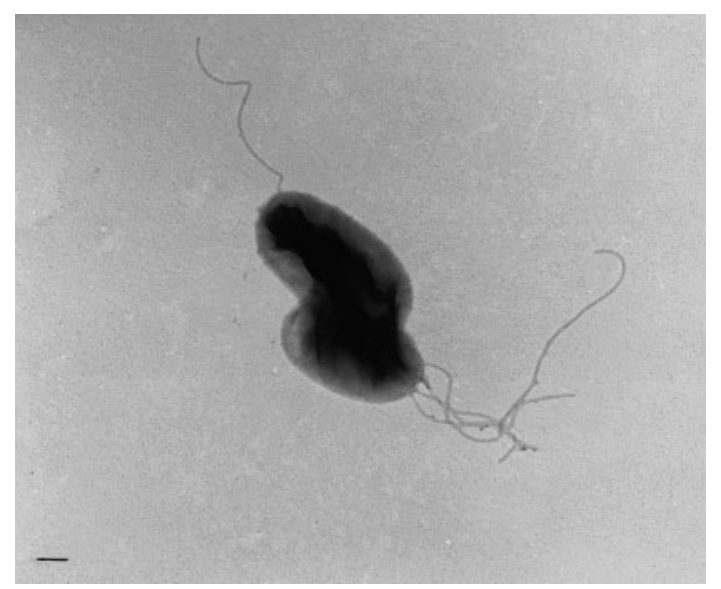

Fig. 1. Electron micrograph of Bartonella chomelii. Bar, $0 \cdot 2 \mu \mathrm{M}$. 


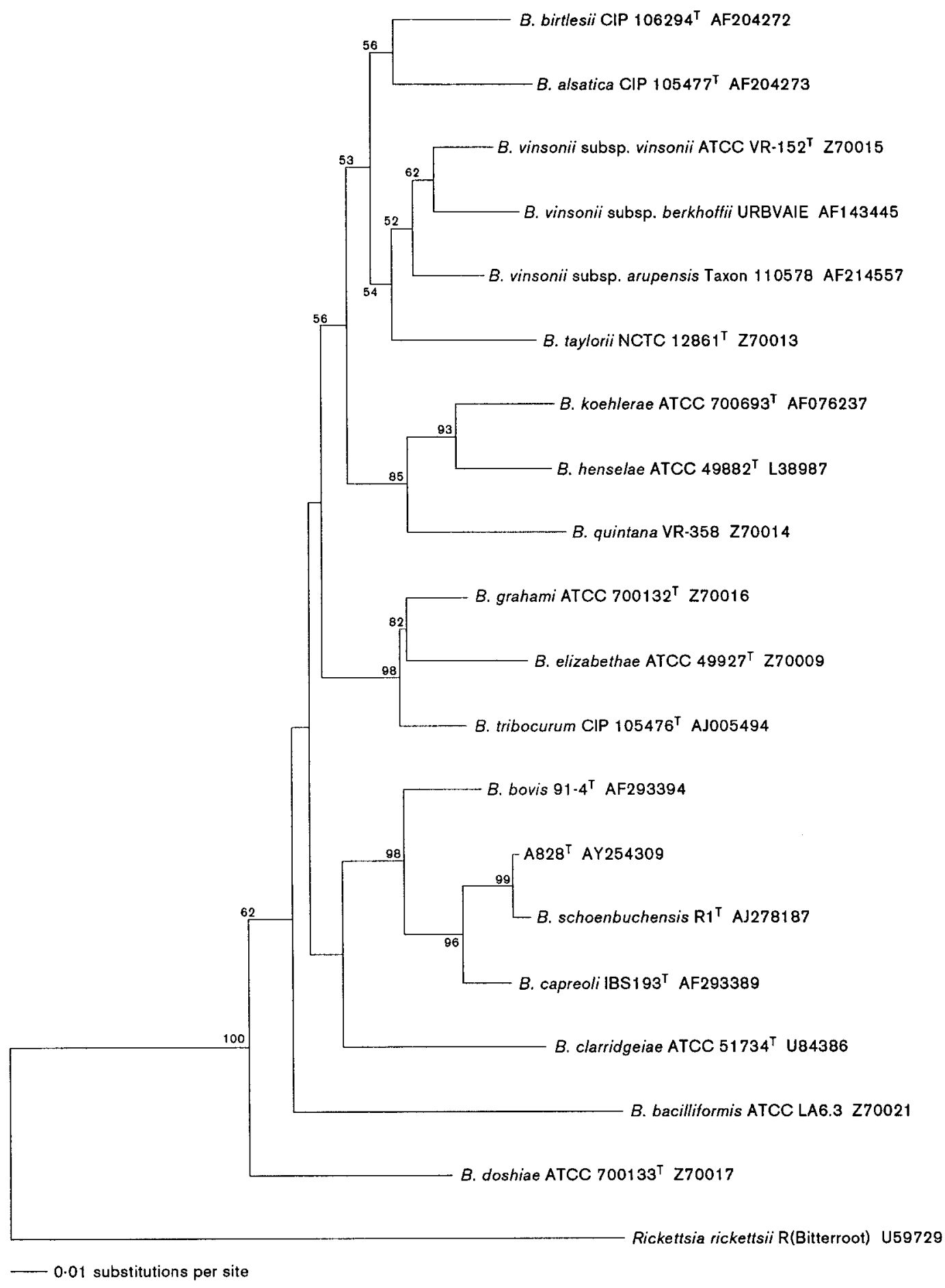

Fig. 2. Phylogenetic relationships of Bartonella species inferred from citrate synthase sequences. The presented phylogram resulted from bootstrapped datasets (Felsenstein, 1985) using parsimony analysis (heuristic search option in PAUP 4.0; Swofford, 1993). This tree was identical to the tree generated from the branch-and-bound algorithm in PAUP 4.0. The percentages above the branches are the frequencies with which a given branch appeared in 500 bootstrap replications. Bootstrap values below $60 \%$ are not displayed. Branch length corresponds to mean amino acid changes assigned to each branch by PAUP 4.0. The sequence from Rickettsia rickettsii was chosen as outgroup. 
microscopic appearance of the bacteria) and the recovery of the bacteria from the blood of cows, all supported the classification of these two isolates within the genus Bartonella.

To investigate whether they defined a new Bartonella species, DNA-DNA hybridization was performed.

\section{DNA-DNA hybridization}

DNA of isolate $A 828^{\mathrm{T}}$ was labelled and hybridized against unlabelled DNA of A12.90 and 16 type/reference strains. The extent of hybridization between $A 828^{\mathrm{T}}$ DNA with heterologous DNA was $78 \%$ with isolate A12.90, 56.5\% with Bartonella schoenbuchensis, $52 \%$ with Bartonella capreoli, $31.5 \%$ with Bartonella bovis and less than $20 \%$ with other Bartonella species. Considering that when DNA-DNA hybridization exceeds $70 \%$ two isolates belong to the same species, a novel species was identified (Grimont et al., 1980). $\mathrm{A} 828^{\mathrm{T}}$ and $\mathrm{A} 12.90$ were shown to belong to the same species since their degree of hybridization exceeded $70 \%$. Isolate $\mathrm{A} 828^{\mathrm{T}}$, though phylogenetically close to other Bartonella ruminant-derived species, was clearly different from them. Among the ruminant-derived Bartonella species, the new species appeared to be more closely related to species recovered from wild ruminants (Bartonella capreoli and Bartonella schoenbuchensis) than to Bartonella bovis.

\section{Sequence alignment and tree construction}

The comparison of aligned 16S rRNA sequences was carried out on 1318 positions, including gaps, for a total of 20 taxa. Among those positions, 1090 were constant characters and only 38 were parsimony-informative characters. The phylogenetic analysis inferred from the $16 \mathrm{~S}$ rRNA sequence comparison clearly demonstrated that A828 ${ }^{\mathrm{T}}$ clustered with other ruminant-derived Bartonella species, Bartonella capreoli, Bartonella schoenbuchensis and Bartonella bovis (Bermond et al., 2002) (available as supplementary data in IJSEM Online). Phylogenetic analyses, neighbour-joining, and heuristic and branch-and-bound searches produced topologically similar trees, although statistical support for the branches varied (data not shown). All analyses distinguished four monophyletic groups; the first comprised $\mathrm{A} 828^{\mathrm{T}}$ along with the three already described Bartonella species from ruminants, the second contained Bartonella taylorii, Bartonella birtlesii, Bartonella doshiae and Bartonella vinsonii subsp. vinsonii, the third was composed of Bartonella koehlerae and Bartonella henselae and the fourth contained Bartonella tribocorum and Bartonella elizabethae. These groups were clearly separated with branches supported by 79, 59, 79 and $82 \%$ bootstrap values, respectively. The comparison of aligned citrate synthase sequences was carried out on 289 characters. Among these, 142 were constant and 81 were parsimonyinformative characters. The phylogenetic analyses inferred from gltA amino acid sequences were in accordance with those inferred from 16S rRNA sequences (Fig. 2). The new species clustered with Bartonella capreoli, Bartonella bovis and Bartonella schoenbuchensis in a group supported by a $96 \%$ bootstrap value. Additional groupings could be distinguished and the species Bartonella bacilliformis was in a paraphyletic position.

\section{Description of Bartonella chomelii sp. nov.}

Bartonella chomelii (cho.mel'i.i. N.L. gen. n. chomelii in honour of Bruno B. Chomel, who was the first to experimentally demonstrate the transmission of Bartonella henselae by fleas in cats, and to isolate Bartonella bovis from domestic cattle. His studies on Bartonella infection in animals contributed to an improved understanding of epidemiology and vectors of Bartonella-associated disease in animals.)

Colonies, grown on rabbit blood agar, appeared homogeneous, smooth, round and grey-white. Electron microscopic examination revealed small bacilli with unipolar flagellae. A primary culture strain of Bartonella chomelii was obtained after 10 days incubation at $35^{\circ} \mathrm{C}$ in a moist atmosphere containing $5 \% \mathrm{CO}_{2}$. A subculture on blood agar was obtained after 6 days culture under the same conditions. The two strains tested were oxidase- and catalase-negative, had negative Voges-Proskauer reactions and had a positive reaction to tributyrin. Amino acid arylamidase activity was obtained with the following amino acids: arginine (ArgA), proline (ProA), phenylalanine (PheA), leucine (LeuA), tyrosine (TyrA), alanine (AlaA) and glycine (GlyA). The new species was distinguished from other Bartonella species by its 16S rRNA gene and gltA gene $3^{\prime}$ end sequences as well as by whole-DNA hybridization. The type strain, $\mathrm{A} 828^{\mathrm{T}}$ (isolated from the blood of Bos taurus), has been deposited in the CIP, Paris, France (CIP $107869^{\mathrm{T}}$ ) and in the Culture Collection of the University of Göteborg, Sweden (CCUG 47497).

\section{ACKNOWLEDGEMENTS}

We are grateful to Dr Jennifer Richardson (UMR 1161, INRA, Ecole Nationale Vétérinaire d'Alfort, France) for kindly reviewing the manuscript.

\section{REFERENCES}

Alexander, B. (1995). A review of bartonellosis in Ecuador and Colombia. Am J Trop Med Hyg 52, 354-359.

Bermond, D., Boulouis, H. J., Heller, R., Van Laere, G., Monteil, H., Chomel, B. B., Sander, A., Dehio, C. \& Piemont, Y. (2002). Bartonella bovis Bermond et al. sp. nov. and Bartonella capreoli sp. nov., isolated from European ruminants. Int J Syst Evol Microbiol 52, 383-390.

Birtles, R. J. (1995). Differentiation of Bartonella species using restriction endonuclease analysis of PCR-amplified 16S rRNA genes. FEMS Microbiol Lett 129, 261-265.

Birtles, R. J. \& Raoult, D. (1996). Comparison of partial citrate synthase gene ( gltA) sequences for phylogenetic analysis of Bartonella species. Int J Syst Bacteriol 46, 891-897. 
Breitschwerdt, E. B. \& Kordick, D. L. (2000). Bartonella infection in animals: carriership, reservoir potential, pathogenicity and zoonotic potential for human infection. Clin Microbiol Rev 13, 428-438.

Chang, C. C., Chomel, B. B., Kasten, R. W., Romano, V. \& Tietze, N. (2001). Molecular evidence of Bartonella spp. in questing adult Ixodes pacificus ticks in California. J Clin Microbiol 39, 1221-1226.

Chang, C. C., Hayashidani, H., Pusterla, N., Kasten, R. W., Madigan, J. E. \& Chomel, B. B. (2002). Investigation of Bartonella infection in ixodid ticks from California. Comp Immunol Microbiol Infect Dis 25, 229-236.

Chomel, B. B., Kasten, R. W., Floyd-Hawkins, K. \& 7 other authors (1996). Experimental transmission of Bartonella henselae by the cat flea. J Clin Microbiol 34, 1952-1956.

Dehio, C., Lanz, C., Pohl, R., Behrens, P., Bermond, D., Piemont, Y., Pelz, K. \& Sander, A. (2001). Bartonella schoenbuchii sp. nov., isolated from the blood of wild roe deer (2001). Int J Syst Evol Microbiol 51, 1557-1565.

Felsenstein, J. (1985). Confidence limits on phylogenies: an approach using the bootstrap. Evolution 39, 783-791.

Fusseneger, M., Kahrs, A. F., Facius, D. \& Meyer, T. F. (1996). Tetrapac ( $t c p)$, a novel genotype of Neisseria gonorrhoeae affecting epithelial cell invasion, natural transformation competence and cell separation. Mol Microbiol 19, 1357-1372.

Grimont, P. A. D., Popoff, M. Y., Grimont, F., Coynault, C. \& Lemelin, M. (1980). Reproducibility and correlation study of three deoxyribonucleic acid hybridization procedures. Curr Microbiol 4, 325-330.

Heller, R., Artois, M., Xemar, V., De Briel, D., Gehin, H., Jaulhac, B., Monteil, H. \& Piemont, Y. (1997). Prevalence of Bartonella henselae and Bartonella clarridgeiae in stray cats. J Clin Microbiol 35, 1327-1331.
Houpikian, P. \& Raoult, D. (2001a). 16S/23S rRNA intergenic spacer regions for phylogenetic analysis, identification, and subtyping of Bartonella species. J Clin Microbiol 39, 2768-2778.

Houpikian, P. \& Raoult, D. (2001b). Molecular phylogeny of the genus Bartonella: what is the current knowledge? FEMS Microbiol Lett 12, 2001-2007.

Jensen, W. A., Majilindez, Z. F., Rooney, J., Kordick, D. L. \& Breitschwerdt, E. B. (2000). Rapid identification and differentiation of Bartonella species using a single-step PCR assay. J Clin Microbiol 38, 1717-1722.

Joblet, C., Roux, V., Drancourt, M., Gouvernet, J. \& Raoult, D. (1995). Identification of Bartonella (Rochalimaea) species among fastidious Gram-negative bacteria on the basis of the partial sequence of the citrate-synthase gene. J Clin Microbiol 33, 1879-1883.

La Scola, B., Zeaiter, Z., Khamis, A. \& Raoult, D. (2003). Genesequence-based criteria for species definition in bacteriology: the Bartonella paradigm. Trends Microbiol 11, 318-321.

Norman, A. F., Regnery, R., Jameson, P., Greene, C. \& Krause, D. C. (1995). Differentiation of Bartonella-like isolates at the species level by PCR-restriction fragment length polymorphism in the citrate synthase gene. J Clin Microbiol 33, 1797-1803.

Riegel, P., de Briel, D., Prevost, G., Jehl, F. \& Monteil, H. (1994). Genomic diversity among Corynebacterium jeikeium strains and comparison with biochemical characteristics and antimicrobial susceptibilities. J Clin Microbiol 32, 1860-1865.

Saitou, N. \& Nei, M. (1987). The neighbor-joining method: a new method for reconstructing phylogenetic trees. Mol Biol Evol 4, 406-425.

Swofford, D. L. (1993). PAUP: phylogenetic analysis using parsimony. Illinois Natural History Survey, Champaign, IL, USA.

Thompson, J. D., Gibson, T. J., Plewniak, F., Jeanmoulin, F. \& Higgins, D. G. (1997). The CLUSTAL X windows interface: flexible strategies for multiple sequence alignment aided by quality analysis tools. Nucleic Acids Res 25, 4876-4882. 